\title{
English summaries/danske resuméer
}

English summaries of Danish- and German-language articles / danske resuméer af engelsk- og tysksprogede artikler

Breve til Marie Toft fra 1840 'erne

Jette Holm

Letters to Marie Toft from the 1840 es

Letters exchanged between Grundtvig and Marie Toft, his second wife, have been destroyed, except for one letter that Toft wrote to Grundtvig in 1847 and an unfinished, unsent one he wrote to her in 1848. Grundtvig's letter is transcribed here together with seven others to Marie Toft, from P.A. Fenger, J.F. Fenger and J.G. Willemoes, which collectively shed light on Marie Toft's thinking in the early 1840s, when a religious revival was taking place in Western Zealand. The letters show Toft becoming involved in the movement and, later, increasingly attracted to Grundtvig and his theology. 


\section{Grundtvigs Brorson}

\section{Sune Auken og Johan Damsgaard}

\section{Grundtvig’s Brorson}

The article analyzes Grundtvig's relationship to Brorson's hymns. It consists of three parts. The first presents Grundtvig's limited prose writings about Brorson; the second describes what Grundtvig's versions of Brorson's hymns look like and presents examples of how (and, to an extent, why) Grundtvig makes changes in what Brorson wrote; and the third part analyses Grundtvig's seven different versions of Brorson's hymn "Den yndigste rose er funden" [The lovliest rose has been found]. The article concludes with some final reflections on Grundtvig's practice of revising Brorson's hymns. It places these revisions in their generic context, compares them with Grundtvig's overall practices as a reviser of hymns, and cautiously points towards their respective roles in later Danish church life. Three accompanying appendixes overview Grundtvig's rewritings of Brorson's texts. 
The Genesis of a Poem

K.E. Bugge

Tilblivelsen af et digt

I sit store digt I Kveld blev der banket paa Helvedes Port beskriver Grundtvig Jesu nedfart til de dødes rige. Digtet, der for første gang blev trykt i 1837, har i perioder været genstand for intensiv forskning. Det er fastslået, at både kirkefaderen Irenæus og den angelsaksiske digter Cædmon helt afgørende har inspireret tilblivelsen. Ikke desto mindre tilbagestår spørgsmålet om, hvornår og under hvilke nærmere omstændigheder digtet er skrevet.

Grundtvig har kendt nedfartsmotivet i 1. Peters brev kap. 3 allerede fra sin barndom og ungdom. I de tidlige år synes motivet dog ikke at have gjort særligt indtryk på ham. I 1815-17 stifter Grundtvig under sine tidligste angelsaksiske studier bekendtskab med Cædmons bibelparafrase, som han vurderer positivt, men med kritiske forbehold. Først i årene 1823-24 udvikler han under påvirkning fra Irenæus en entydig positiv holdning over for dette led af den apostolske trosbekendelse.

Under sine Englandsrejser i 1829-31 studerer Grundtvig bl.a. manuskripterne til Cædmons behandling af nedfarten. Atter hjemme i Danmark bliver Grundtvig hurtigt optaget af arbejdet med Nordens mytologi og verdenshistorien. Endvidere engagerer han sig i den offentlige debat om forholdet mellem stat og kirke. Først i 1835 påbegyndes arbejdet med den salmeudgave, han for år tilbage havde lovet vennen Gunni Busck. Selv om de angelsaksiske studier kommer noget på afstand under disse mangfoldige tiltag, blev Grundtvig i årene 1831-35 gang på gang mindet om nedfartsmotivet. I den offentlige debat blev netop nedfarten ofte inddraget $\mathrm{i}$ de gudelige forsamlingers opposition mod statskirken og dens præster. I denne debat spillede ugeskriftet Nordisk Kirke-Tidende en fremtrædende rolle. Tidsskriftet redigeredes af Grundtvigs medkæmper Jacob Christian Lindberg, og Grundtvig bidrog med digte og artikler. Lindbergs udførligste bidrag, der er en artikelserie på 80 spalter, omhandler netop nedfarten. Artiklen kom i 1835.

I de første måneder af 1836 ligger arbejdet med salmerne stille. I januar er Grundtvig dybt deprimeret. I februar-marts melder en ny inspiration 
sig, og Grundtvig skriver sit første større højskoleskrift, Det Danske FiirKløver. I den situation har han ikke tid til at digte salmer. Arbejdet med "Fiir-Kløveret" har imidlertid bibragt Grundtvig en optimisme, der i tiden efter påske inspirerer ham til at genoptage salmearbejdet i sidste halvdel af april. Torsdag d. 12.51836 prædiker han på Kristi himmelfartsdag. I denne prædiken foretager han en udførlig kombination af Jesu nedfart og himmelfart. I Kveld er derfor sandsynligvis på denne baggrund digtet i første halvdel af maj 1836. Det påvises, at andre tilblivelsesperioder i 1836-37 ikke er sandsynlige. 
Grundtvig's I Kveld: Some reflections of an Anglo-Saxonist

\section{S.A.J. Bradley}

Grundtvigs I Kveld: Nogle overvejelser fra et angelsaksisk perspektiv

Med henblik på udgivelse i første bind af Sang-Verk til den Danske Kirke (1837) skrev Grundtvig en række digte, der var inspireret af emner, tanker og udtryksformer anvendt af digtere fra den tidlige middelalder inden for den angelsaksiske kirke. Denne indoptagelse af en stemme fra den angelsaksiske kristenhed var udsprunget af hans grundlæggende ønske om at illustrere den kristne kirkes katolicitet (universalitet). Samtidigt opnåede han at skænke den danske kirke et stort antal salmer, der kunne udtrykke denne universelle virkelighed, inden for hvilken også den danske kirke havde sin egen helt særlige rolle.

Tre af disse angelsaksiske tekster og Grundtvigs brug af dem kommenteres her på grundlag af angelsaksiske studier. Formålet er at identificere og vurdere nogle af de sammenhænge, hvor Grundtvig fra oldkirkelige kilder ikke alene øser inspiration og vejledning til gavn for samtidens menighed, men også gives våben i hænde til at fastholde et markant særstandpunkt i sit aktuelle teologiske, liturgiske og kirkepolitiske opgør.

De tre danske tekster, der var inspireret af angelsaksisk digtning, er $I$ Kveld blev der banket paa Helvedes Port, Kommer Sjale, dyrekiøbte og Himmel-Farten saae i Løn / Salomon, Kong Davids Søn. En ny metrisk, urimet engelsk oversættelse af I Kveld bliver her fremlagt ledsaget af nogle nødvendige kommentarer. Herunder inddrages Grundtvigs forhold til hans vigtigste litterære kilde, det apokryfe Nicodemus-Evangelium. Nogle af de vigtigste og mest afgørende emner drøftes særlig udførligt, herunder Grundtvigs behandling af Eva-skikkelsen.

Endvidere inddrages Grundtvigs vedholdende og i samtiden omdiskuterede sammenkædning af Kristi nedstigning til helvede og derpå følgende himmelfart. Denne sammenkædning spiller også en væsentlig rolle i K.E. Bugges redegørelse. 